\title{
Studies on Different Levels of NPK with Combination of FYM on Growth, Mortality and Establishment of Kinnow (Citrus reticulata Blanco) Under Subtropical Condition
}

\author{
Murli Manohar Vaishnav, Sandeep Singh and Saket Mishra*
}

Department of Horticulture, Sam Higginbottom University of Agriculture, Technology and Sciences, Allahabad (U.P.) 211007, India

*Corresponding author

\section{A B S T R A C T}

\begin{tabular}{|c|}
\hline Keywords \\
\hline $\begin{array}{l}\text { Kinnow, Citrus } \\
\text { reticulate Blanco, } \\
\text { FYM, NPK, } \\
\text { Growth, Mortality. }\end{array}$ \\
\hline Article Info \\
\hline $\begin{array}{l}\text { Accepted: } \\
\text { 21 June } 2017 \\
\text { Available Online: } \\
\text { 10 July } 2017\end{array}$ \\
\hline
\end{tabular}

The present investigation was under taken at Department of Horticulture, Sam Higginbottom University of Agriculture, Technology and Sciences, Allahabad, India during 2013-14. The experiment was laid out in randomized block design with three replications and 13 treatments, separately. The materials used in the investigation were organic manures and inorganic fertilizers (NPK). Results showed significant effect on maximum plant height $(80.13 \mathrm{~cm})$, number of branches $(16.96)$, number of leaves $(176.00)$, leaf length $(6.70 \mathrm{~cm})$, maximum plant establishment percentage $(100 \%)$, and minimum mortality percentage $(00.00 \%)$ was in treatment $\mathrm{T}_{8}$ and $\mathrm{T}_{4} @ 5 \mathrm{~kg}$ per plant Farm Yard Manure $+60 \mathrm{~g}$ per plant Nitrogen, 35g per plant Phosphorus and 25g per plant Potash under Allahabad agro climatic conditions.

\section{Introduction}

Citrus is one of the leading tree fruit crops of the world. The genus citrus includes over 162 species belonging to the Order Geraniales, family Rutaceae and sub family Aurantoideae (Tanka 1977). It would appear that all the species belonging to citrus and its related genera originated in the tropical and subtropical regions of South-east Asia north-eastern India, Southern China, IndoChinese peninsula, Malay Archipelago, and then spread to other continents, (Webber, 1967; Chapot, 1975). Among the citrus sp. 8 sp. generally cultivated for edible purpose are: Mandarin (Citrus reticulata Blanco), Sweet orange ( $C$. sinensis Osbeck), Grapefruit ( $C$. paradisi Mac Fadyen), Pummelo (C. grandis Osbeck), Acid Lime (C. aurantifolia Christm), sour orange (Citrus aurantium Linnaeus), Lemon (C. limon Burmann) and citron (Citrus medica Linnaeus) (Purseglove 1968) are commercially grown worldwide. Citrus is mainly grown in United States, Brazil, Mexico, India and Argentina. After Mexico, India is the leading producer of citrus fruits with an area of 763 lakh hectares with production of 599 lakh tones annually. In India, it ranks third in production after banana and mango. Among citrus crops, mandarin 
orange (Kinnow mandarin, Nagpurmandarin, Khasimandarin and Darjling mandarin) covers largest area followed by sweet orange varieties (Musambi, Pineapple, Blood Red and Jaffa) and Acid lime. Mandarin is also known as loose skinned orange. Mandarins are classified in to four groups -Satsuma, King, willow- leaf and common mandarin Hodgson (1967). Among these, Kinnow mandarin bears highest place in production, productivity, juice content and fruit quality. In India, Kinnow is being grown in Punjab, Rajasthan, Haryana, Himachal Pradesh, Jammu and Kashmir and Uttar Pradesh. There are different kinds of citrus such as kinnow, sweet oranges group, Grapefruit, Local mandarin, Lemon, Lime, Sweet lime, Tangelos and Tangerines. In Rajasthan, Sriganganagar district is on prime position with 8650 hectares area and 25000 million tonne production followed by Hanumangarh district (Anonymous, 2008). The interest of farmers in adoption of Kinnow cultivation is increasing due to suitable agro-climatic conditions, higher crop yield and demand in international market.

\section{Materials and Methods}

The present studies were carried out during the winter season of the year 2013-2014 at Pomology Research Farm Department of Horticulture, Sam Higginbottom University of
Agricultural, Technology and Sciences. The experimental area had sandy loam soil with $\mathrm{pH}$ of 7.2, the soil was moderately fertile. The plant of kinnow was planted at beginning of rainy season with $(6 \mathrm{mX} 6 \mathrm{~m}$ spacing $)$ of commercial variety of Citrus viz. Kinnow. The plants were planted in Randomized Block Design putting 4 plants per treatment per replication. The planting method used in kinnow is square method. Data were recorded on different growth parameters.

\section{Results and Discussion}

The present investigation was conducted in year 2013-2014, at the Central Research field, Department of Horticulture, Sam Higginbottom University of Agriculture, Technology and Sciences, Allahabad. The maximum plant height was recorded at 150 days in $\left(\mathrm{T}_{4}\right),(80.13 \mathrm{~cm})$ (Fig. 1), maximum number of Branches was recorded at 150 days in $\left(\mathrm{T}_{8}\right)$ (Fig. 2), (16.96), maximum number of Leaves was recorded at 150 days in $\left(\mathrm{T}_{8}\right)$, (176.00), maximum Leaf length was recorded for 150 days in $\left(\mathrm{T}_{8}\right),(6.70 \mathrm{~cm})$, maximum Plant establishment Percentage was recorded in 150 days $\left(\mathrm{T}_{8}\right)$ and $\left(\mathrm{T}_{12}\right)$ produced significantly better establishment (100\%), minimum mortality percentage was recorded in $\left(\mathrm{T}_{8}\right)$ followed by $\left(\mathrm{T}_{12}\right)$ with no mortality $(00.00 \%)$ (Table 1$)$.

\section{Citrus reticulata Blanco}

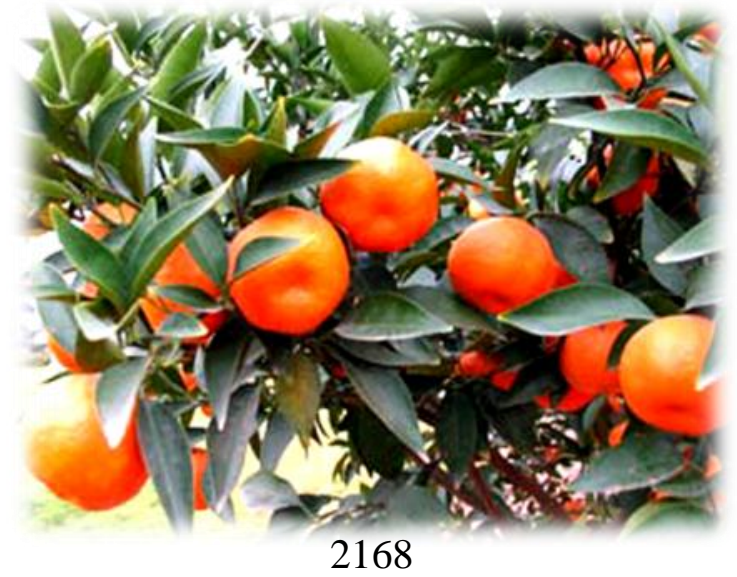


Treatments combinations

\begin{tabular}{|c|c|}
\hline Treatment & Combination \\
\hline $\mathbf{T}_{\mathbf{0}}$ & $5 \mathrm{~kg} \mathrm{FYM}$ \\
\hline $\mathrm{T}_{1}$ & $5 \mathrm{~kg} \mathrm{FYM}+40 \mathrm{gN}+25 \mathrm{gP}+25 \mathrm{gK}$ \\
\hline $\mathrm{T}_{2}$ & $5 \mathrm{~kg} \mathrm{FYM}+45 \mathrm{gN}+25 \mathrm{gP}+25 \mathrm{gK}$ \\
\hline $\mathrm{T}_{3}$ & $5 \mathrm{~kg} \mathrm{FYM}+55 \mathrm{gN}+25 \mathrm{gP}+25 \mathrm{gK}$ \\
\hline $\mathrm{T}_{4}$ & $5 \mathrm{~kg} \mathrm{FYM}+60 \mathrm{gN}+25 \mathrm{gP}+25 \mathrm{gK}$ \\
\hline $\mathrm{T}_{5}$ & $5 \mathrm{~kg} \mathrm{FYM}+50 \mathrm{gN}+15 \mathrm{gP}+25 \mathrm{gK}$ \\
\hline $\mathrm{T}_{6}$ & $5 \mathrm{~kg} \mathrm{FYM}+50 \mathrm{gN}+20 \mathrm{gP}+25 \mathrm{gK}$ \\
\hline $\mathrm{T}_{7}$ & $5 \mathrm{~kg} \mathrm{FYM}+50 \mathrm{gN}+30 \mathrm{gP}+25 \mathrm{gK}$ \\
\hline $\mathrm{T}_{8}$ & $5 \mathrm{~kg} \mathrm{FYM}+50 \mathrm{gN}+35 \mathrm{gP}+25 \mathrm{gK}$ \\
\hline $\mathrm{T}_{9}$ & $5 \mathrm{~kg} \mathrm{FYM}+50 \mathrm{gN}+25 \mathrm{gP}+15 \mathrm{gK}$ \\
\hline $\mathrm{T}_{10}$ & $5 \mathrm{~kg} \mathrm{FYM}+50 \mathrm{gN}+25 \mathrm{gP}+20 \mathrm{gK}$ \\
\hline $\mathrm{T}_{11}$ & $5 \mathrm{~kg} \mathrm{FYM}+50 \mathrm{gN}+25 \mathrm{gP}+30 \mathrm{gK}$ \\
\hline $\mathrm{T}_{12}$ & $5 \mathrm{~kg} \mathrm{FYM}+50 \mathrm{gN}+25 \mathrm{gP}+35 \mathrm{gK}$ \\
\hline
\end{tabular}

Table.1 Effect of different levels of NPK with combination of FYM on growth, mortality and establishment of Kinnow mandarin under Allahabad agro-climatic condition"

\begin{tabular}{|c|c|c|c|c|c|c|}
\hline $\begin{array}{l}\text { Character } \\
\text { Treatment }\end{array}$ & $\begin{array}{c}\text { Plant } \\
\text { Height } \\
\text { (cm) 150 } \\
\text { DAT }\end{array}$ & $\begin{array}{c}\text { Number } \\
\text { of } \\
\text { branches } \\
150 \text { DAT }\end{array}$ & $\begin{array}{c}\text { Number } \\
\text { of leaves } \\
150 \\
\text { DAT }\end{array}$ & 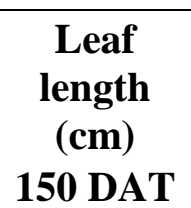 & $\begin{array}{c}\text { Plant } \\
\text { mortality } \\
(\%)\end{array}$ & $\begin{array}{c}\text { Plant } \\
\text { establishm } \\
\text { ent } \\
(\%)\end{array}$ \\
\hline $\mathbf{T}_{\mathbf{0}}$ & 61.200 & 10.233 & 107.00 & 5.10 & 27.22 & 72.22 \\
\hline$T_{1}$ & 63.367 & 11.667 & 116.33 & 5.27 & 22.22 & 77.77 \\
\hline $\mathbf{T}_{2}$ & 66.133 & 12.600 & 124.00 & 5.57 & 16.66 & 83.33 \\
\hline $\mathbf{T}_{3}$ & 69.000 & 14.567 & 134.33 & 5.70 & 22.22 & 77.77 \\
\hline $\mathbf{T}_{4}$ & 80.13 & 15.467 & 153.33 & 5.93 & 16.66 & 83.33 \\
\hline$T_{5}$ & 66.267 & 14.400 & 127.00 & 5.57 & 16.66 & 83.33 \\
\hline$T_{6}$ & 67.433 & 15.133 & 142.00 & 6.00 & 11.12 & 88.88 \\
\hline $\mathbf{T}_{7}$ & 69.367 & 15.000 & 160.33 & 6.33 & 5.55 & 94.44 \\
\hline$T_{8}$ & 70.233 & 16.967 & 176.00 & 6.70 & 00 & 100 \\
\hline $\mathbf{T}_{9}$ & 69.067 & 15.133 & 135.33 & 6.23 & 22.22 & 77.77 \\
\hline$T_{10}$ & 70.833 & 16.000 & 154.33 & 6.33 & 16.66 & 83.33 \\
\hline$T_{11}$ & 73.767 & 16.467 & 163.33 & 6.53 & 11.12 & 88.88 \\
\hline$T_{12}$ & 75.433 & 15.767 & 164.67 & 6.43 & 00 & 72.22 \\
\hline F.test & $\mathrm{S}$ & $\mathrm{S}$ & $\mathrm{S}$ & $\mathrm{S}$ & NS & $\mathrm{S}$ \\
\hline C.D. & 0.97 & 0.517 & 8.19 & 0.21 & 0.47 & 0.47 \\
\hline $\mathrm{SE}(\mathrm{d})$ & 0.47 & 0.249 & 3.95 & 0.10 & 0.97 & 0.97 \\
\hline
\end{tabular}


Fig.1 Effect of different treatments on plant height $(\mathrm{cm}$.

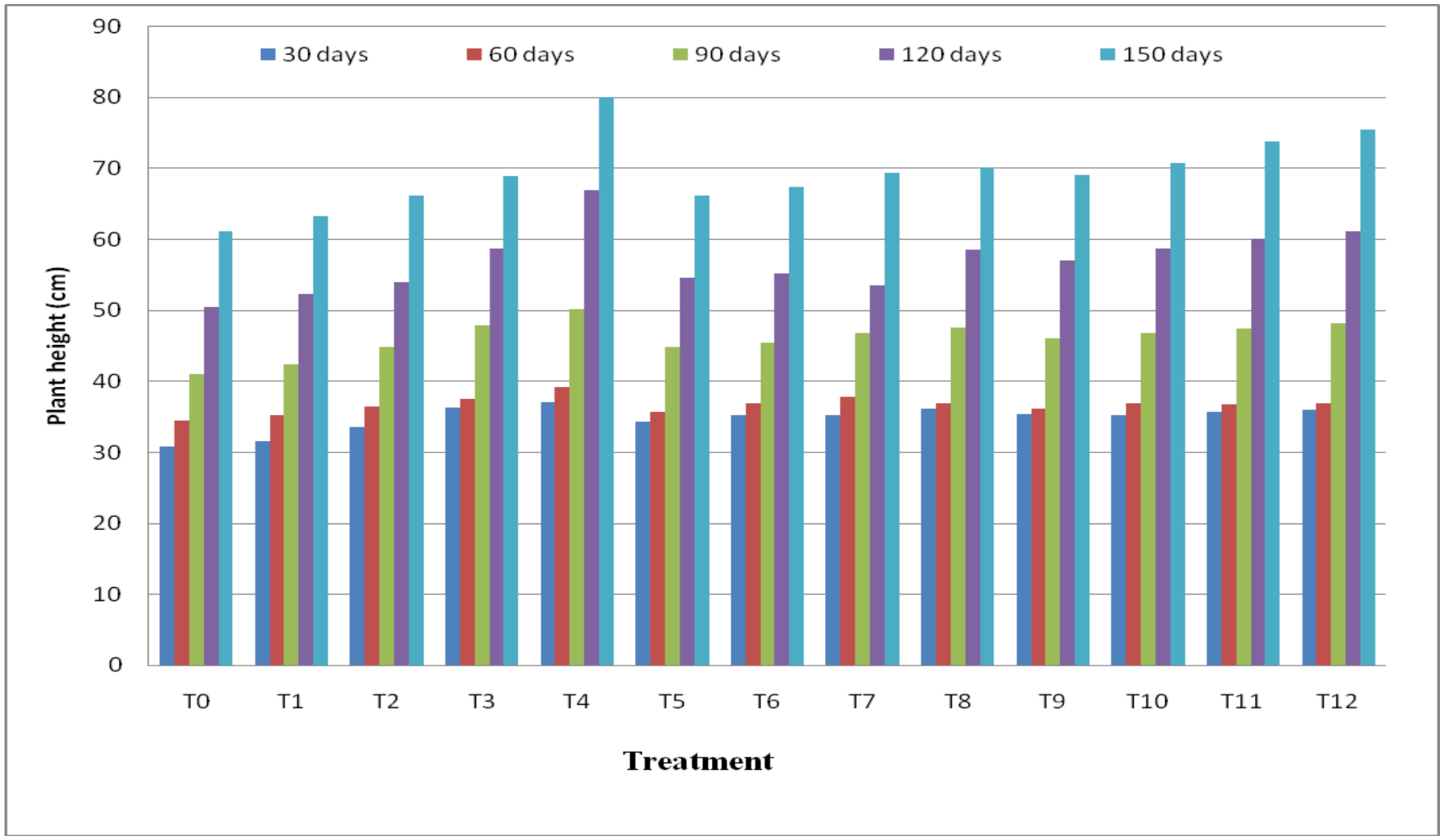

Fig.2 Effect of different treatments on Number of branches per plants

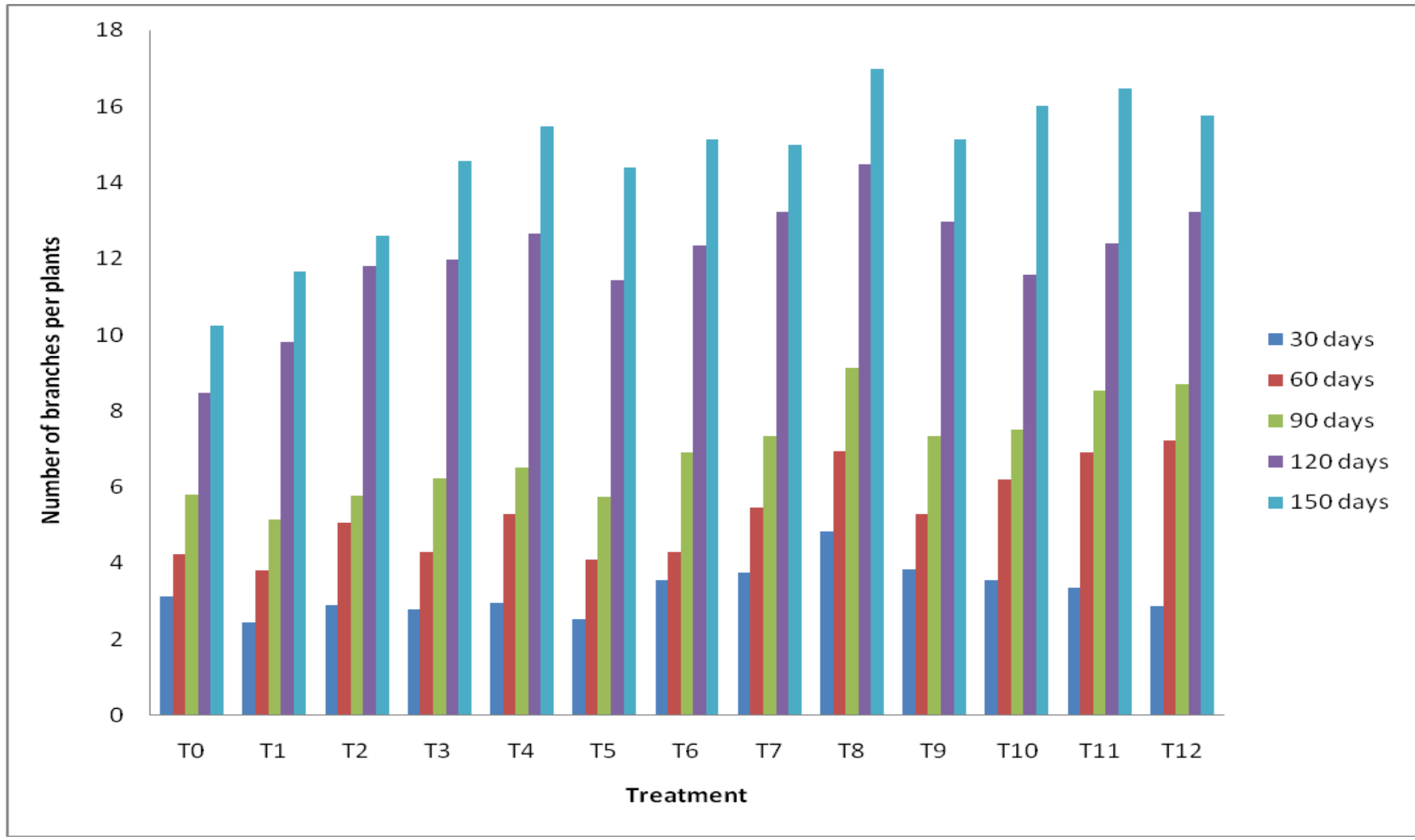


On the basis of results obtained, it is concluded that the treatment $\mathrm{T}_{8}: 5 \mathrm{~kg}$ par plant Farm Yard Manure + 50 g par plant Nitrogen, 35 par plant Phosphorus and 25 g par plant Potash was found to be the best in terms of maximum number of branches (16.96), maximum number of leaves (176.00), maximum leaves length $(6.70 \mathrm{~cm})$, minimum mortality percentage $(00 \%)$, and maximum establishment percentage (100\%), followed by treatment $\mathrm{T}_{12}: 5 \mathrm{~kg}$ par plant Farm Yard Manure $+50 \mathrm{~g}$ par plant Nitrogen, 25g par plant Phosphorus and 35g par plant Potash and the minimum was recorded in $\mathrm{T}_{0}$ : control (27.22\%) but also in terms of plant height the best results found in treatment $\left(\mathrm{T}_{4}\right) 5 \mathrm{~kg}$ par plant Farm Yard Manure + 60 g par plant Nitrogen, 25 g par plant Phosphorus and $25 \mathrm{~g}$ par plant Potash.

\section{References}

Anonymous (2008). Directorate of Economics and Statistics, Department of Agriculture and Co-operation and Department of Commerce.

Chapot, H. (1975). The citrus plant In: Citrus
Technical Monograph, no. 4. CibaGeigy Agrochemicals, pp.613.

Hodgson, R. W. (1967) In: Citrus Industries, Vol. I (Eds. W. Reuther, H. J. Webber, and L. D. Batchelor), Univ. California, Berkeley.

P. C. Garhwal, P. K. Yadav, B. D. Sharma, R. S. Singh and A. S. Ramniw (2013).Effect of organic manure and nitrogen on growth, yield and quality of kinnow mandarin in sandy loam soil of hot arid region. African Journal of Agriculture Researchvol. 9(34), pp - 2638-2647

Purseglove, (1968). Tropical crops, Dicotyledons, Longman, pp. 493-522

Tanaka, T. (1977). Fundamental discussion of citrus classification. Studia citrologica, 14(1): 6 .

Webber, H.J. (1967). History and development of the Citrus industry. In: Reuther, W., Batchelor, L.D. andWebber, H.J. (Eds) The Citrus Industry, 2nd edn. University of California Press, California, pp. 1-39.

\section{How to cite this article:}

Murli Manohar Vaishnav, Sandeep Singh and Saket Mishra. 2017. Studies on Different Levels of NPK with Combination of Fym on Growth, Mortality and Establishment of Kinnow (Citrus Reticulata Blanco) Under Subtropical Condition. Int.J.Curr.Microbiol.App.Sci. 6(7): 21672171. doi: https://doi.org/10.20546/ijcmas.2017.607.254 